\title{
Research of Media Overall Listing: Taking Published Media as an Example
}

\author{
Rong Zhang (Corresponding author) \\ School of Government, Sun Yat-Sen University, Guangzhou 510275, China \\ E-mail: rose66rose66@163.com
}

Fanbin Zeng

School of Journalism and Communication, Jinan University, Guangzhou 510632, China

E-mail: zengfanbin@vip.sina.com

\author{
Received: December 20, 2011 Accepted: February 8, 2012 Published: March 1, 2012 \\ doi:10.5430/bmr.v1n1p89 \\ URL: http://dx.doi.org/10.5430/bmr.v1n1p89
}

This research thanks for the support by Panmedia Institute ("PMI", http://panmediainstitute.com/) with the items number 20114-008

\begin{abstract}
Overall Listing is to point to a company will be the main assets and business to a joint stock company overall reform listed practice. Liaoning Publish Media choose overall listing not only has the profound policy background, China is the inevitable development of media capital management. Overall listing to detachment from the discard of the listing, stripping listed inevitably caused a lot of related transaction, and not fair trade association of media risks listed companies. Take Liaoning Publish Media as an example, this essay is to analyzes its listed before and after the financial data, and with the A shares of the listed company of media of other financial data comparison analysis, found that Liaoning Publish Media overall listing, in the business performance has improved, and produced the effective market effect, Liaoning Publish Media in the capital operation performance is better than other media companies listed on the media plate. This paper also makes a vista of the overall listing to the media, and points out that the media is only for the overall listing to resolve their own system mechanism provides a platform, overall listing after the enterprise how to use media capital market mechanism change the original low efficiency phenomenon, effectively solve the corporate governance problems, still needs further research.
\end{abstract}

Keywords: Media industry, Overall Listing, Related Transaction

\section{Introduction}

Overall listing is to point to a company will be the main assets and business to a joint stock company overall reform listed practice. The whole of the media market, also called packaging listed, is mainly refers to the media will no longer editors and management split, but complete integration of the group will be listed. Overall media the premise condition of listed is to define the nature of the media, and our country's public media such as the party has not yet listed the necessary, and business media should accord with the requirement of listed, can at the special system arrangement overall listing. Along with the securities regulatory commission of the listed company, the independence of the improvement of the business requirements, overall listing has become the company's first public listing of the main mode. December 21, 2007, Liaoning Publish Media Co., LTD (hereinafter referred to publication medium SH 601999) listed on Shanghai stock exchange. As China's first overall listing media enterprise, published on the day of the share price rise $329.53 \%$ listed media, at 19.93 Yuan, and drive media plate overall rise, shows a good demonstration effect.

Media overall listing is one of the important ways of financing activities, however our country management to the media's financing activities especially stock has been concerns and heavy, worry about its activities would interfere with the disorder of public opinion direction, affect the safety of ideology. As to early 2004, if take no account of network media, our country market directly media enterprise is not much, only GeHua YouXian, DianGuang Media, the Oriental pearl, CTV media four and eight home media enterprise by borrowing shell listed or equity on indirect way into the stock market. In December 2004, Beijing youth daily affiliate "north green media Co., LTD" in the stock exchange of Hong Kong h-shares listed (next said north green media), however, north of the media is essentially to listed by the 
Beijing youth daily business assets (advertising management) and non-business assets (editor business) to peel and realize the market, editor of the cost of business is business assets through the connection transaction and realize. Therefore, north of green media market, is a spin-off listed, not the overall listing. Liaoning Publish Media of the initial plan is listed on the north of green media as templates to split its listed property administration, reserve assets such as book publishing business of independence, but then exposed content and management from question, and, Liaoning Publish Media eventually give up split listed, and choose services overall listing.

The media has a profound policy list on the background. In January 2006, the party central committee and the state council issued "the deepening reform of the cultural system about certain opinions" (hereinafter referred to as the "opinions")(Xinhua Net, 2006). The media has a profound policy list on the background. In January 2006, the party central committee and the state council issued "the deepening reform of the cultural system about certain opinions" (hereinafter referred to as the "opinions"). This is since the establishment of the party central committee and the state council was the first reforms of the cultural system make a big decision. The file to differentiate clearly the cultural undertakings and cultural industries range and boundaries, and first allowed purely for the enterprise culture unit, absorb some of the social capital, the main body of investment diversified stock reform. "Opinions" also explicitly pointed out that, to regulate the state-owned culture institutions factory. The speed up the property rights system reform, and promote the stock system reform, and realize the diversification of investment, perfect the corporate governance structure, the conditions for listing, the approval listing application. "Opinions" issue, especially after 17, in promoting socialist culture greater development and prosperity under the calls, reform of the cultural system into promoting new period, and listed it is an important breakthrough in deepening reform. In December 2007 the publication medium listed realized content and issue the business such as overall listing, the publication of the overall listing the media from policy release, the purpose is to complete reflect the integrity of the industry, reduce the connection transaction, for publishing core competitiveness of the enterprise is to book, rather than around the release, the book printing services. Following the publication medium later, our country has opened by the media industry and to the whole of the listed boom.

\section{Literature review}

In the past, in order to consider the whole country culture safety, to ensure that the party and the state of the news media control, our country to the media industry capital operation into the capital market always remain cautious attitude, media core business also is not listed consider range. Media before published listed in Shanghai, deep, Hong Kong listed media enterprise are high quality business asset stripping out, to be listed on the integration of restructuring, is not content editing non-core business into the listed company, and this led to the media industry chain as separate, and then makes some media stock market because of insufficient growth after that show lack of power. The media business depends on media content, media platform to launch, such as press agency most valuable part is editor business, advertising, publish and other business assets in large part to attached to the editors, and the content of split after stripping listed, on the one hand, is difficult to generate enough investors appeal, on the other hand also influence to the media listed companies to establish a transparent and open of the modern enterprise system, finally go against the media of the listed company of long-term development.

Second, the media enterprise stripping listed, the restructuring the remaining assets of Group Company become public listed companies of the controlling shareholders, inevitably drives a lot of related party transactions. The so-called associated trade, it is to point to the company or a subsidiary company with its associated (also called affiliated parties) on any of the transactions between matters. Associated business is generally exists in modern economic transactions, in theory is neutral. Reasonable connection transaction is possible, but also is allowed, for example, in 1997 the media fail at the beginning of the profit of the listed a respectable, where the net profit more than 70 million Yuan, investors are betting on the future prospect, but subsequent year stay low and to 2002 or even gets a deficit warning. To avoid "delisting" or get stock dividend qualification, actual holding people-the central TV is used association trade the listed company conveying profits, for its financial statements made great contribution, especially at the end of 2002 a week of copyright transaction is actually big shareholders timely help lift(Zhao Shuguang, Zhang Zhi'an,2004), fail to recover the full 2002 media the loss of the negative situation. If, however, the holding company and a listed company more than a certain connection transaction of degree, and with special purpose, you should put a stop to it, this is also the capital market common way for all countries(Luo Zhenglin ,2006).

Especially in split on the market, "a stream of single big, big shareholders to the lack of checks and balances mechanism under the background, the connection transaction often and profit operation forgery, deceive small investors problems relates in together, it has become the China securities market with a persistent ailment. Related research points out that the dangers of related transaction to the company from conflicts of interest theory, interest conflict theory is that related transactions have control over the big shareholders make or management is doing hard to get the regulation, when the 
company governance mechanism weaker, the connection transaction will be quite common, the company the returns on the stock will be more low, can damage the interests of small and medium shareholders, reduce the enterprise value(Li Yanrong ,2007). Although to affiliated party relations and the connection transaction disclosed market supervision constantly improve, but in practice but always not satisfied. Therefore, the stock market supervision department of the connection transaction often have a limit attitude, for example, was north green media is in the mainland to the market, however, as the prevailing north green media $74 \%$ of revenue from advertising, and advertising of the amount of $98 \%$ from the parent company Beijing youth daily, unable to meet at the time, the CSRC "can only had 30\% less income source and parent company association" requirement, make north green media from the mainland to Hong Kong to ZhuanFu listed. However, even if the north green media to Hong Kong listing, but also because met many related transactions, according to the Hong Kong because of regulatory authorities regulation, when the connection transaction exceed constant, big shareholders don't have the say, need from small shareholders voted to, and small shareholders to consider their own interests, often can't formation and holding big shareholders similar judgment, so directly to the development of the north green newspaper brings the risk of operation, and north green media in the listed appears after the problems and fully proved it.

In order to solve the problem of stripping listed, media began to implement overall listing, the overall listing to stripping from the discard of the listed. However, overall media also means that the power of the capital listed in our country will be penetration in the ideology of the supervision, this will give the cultural security in China have brought some hidden trouble. In addition, after overall listing, still can hide some policy risk, such as our country the paper system, deeds once media company newspaper the Numbers be revoked, then Media Company will lose legitimacy, even if it's in the capital market to function well, will lose everything. In view of our country the particularity of the media, the whole of the China's media to the media and the state must be listed on the parallel control, how to coordinate the contradiction, the need for innovation of financial instruments and the system arrangement, such as the golden share or explore set $\mathrm{A}$ and B shares, GuanLiGu and common stock system. And this kind of special arrangement of system, the domestic enterprise there has been cases. As in 2007 in July, in Harbin property rights trading center for the transfer of the Harbin ZhongQing gas limited company of equity cases, Harbin city of state-owned assets supervision ZhongQing gas, the shareholding percentage will from $49 \%$ to $1 \%$, and the $1 \%$ stake in Harbin city people's government for "gold shares," city people's government on behalf of state-owned assets supervision in Harbin city enjoys major matters veto, namely "gold shares" voting rights, when he ZhongQing gas involved in the safety and stability of the gas supply and other important questions, Harbin city can exercise the power of the sasac veto.

In addition, acquirers' promise that has equity in the state-owned assets supervision ZhongQing, the board of directors at least has director seats(Zhao Tonggang, Wang Guangping,2007). In fact, the publication medium of overall listing are also introduced the system arrangement: one is "publishing decision-making rights" published by the Liaoning province administrative organization ChuBanJu direct control of Liaoning province, the publication medium selected topic contents and to strictly control quality; Two is to ensure that the state-owned capital in the company's internal absolutely holding status and discourse; Three is the guarantee of party organizations vertical right, to ensure that Liaoning publishing group company party organization to Liaoning Publish Media and subordinate company of the leadership of the party committee management. Of course, these institutional arrangement of how the effect, still need time to inspection.

\section{Methodology}

Whether the overall listing will promote the development of the operations of the media? And the whole of the media company listed on the stock market in the media industry plate performance how? In order to further explore these questions, this article selects the Liaoning Publish Media listed before and after the financial data for analysis. In this paper the financial network reference with dispatch data, the selection of the 2005 to 2009 annual Liaoning Publish Media listed before and after the profitability, operation ability, debt paying ability three indicators to analyze its performance.

\subsection{The development of the listed and comparative analysis}

And Beiqing Media listed contrast different media before and after, Liaoning Publish Media showed steady development, its specific performance the following three aspects: first, profitability. Liaoning Publish Media 2005 to 2009 earnings per share, net worth and net assets per share in the growth rate of return basically, and profit rate of main business (\%), interest pre-tax profit margins (\%), total return on assets (\%) basic maintain a stable level. Second, come to the operation ability, 2009 years of total asset turnover and accounts receivable turnover declined, but very small drop. It shows that the company for their own resources development and the use would be further developed. Third, come to the debt paying ability, 2007 to 2009 years after the fall of assets and liabilities rises, and the current ratio and during the 
hydraulic/than after drop that Liaoning Publish Media in constant adjustment cash flow, to adapt to the challenges of the environment. The whole point of view, Liaoning Publish Media listed and got a lot of assets, and to reduce the debt ratio, and increase the profit ability, but also need to further development operation ability.

Understand the Liaoning Publish Media of the development of the listed before and after the comparison, we further analyzed the Liaoning Publish Media in the media industry. According to the classification of the listed company industry guidelines ", media are covering publishing industry (books, newspaper, magazine, material and software publishing), audio-visual industry (vocal music and video products industry), radio, film and television (radio, film and television), art industry, information transmission services and Internet and many other fields of the industry. In order to maintain consistent with other research, this paper chose to media industry as its main business, and for media industry has a large investment of China's 12 shares listed companies (including publication media) financial data are compared and analyzed. The 12 companies' affiliate of industry, business and related media segments are as follows:

According to table 3 and table 4, we further analysis published the operations of media and financial conditions:

\subsection{Business Condition Analysis}

As the strongest comprehensive analysis of the financial indicators, net assets yield rate reflects the period of the enterprise of the total amount of the net profit and shareholders' equity ratio, is a reflection of the shareholders of their invested capital profitability of very important composite index. According to the 200912 home media the financial statements of the listed company, DuPont analysis found that, the net assets of the publication medium yields $8.81 \%$, in 12 listed company 6 out of, and other financial indicators such as total asset yield 6.18\%, ranking fifth, sales net interest rate $10.01 \%$, ranking sixth. And the total asset turnover ratio is a comprehensive evaluation of the company all assets management quality and the use efficiency of important index, total asset turnover is to show the enterprise is in certain period net revenue with the ratio of average total assets, publishing media total asset turnover 0.62 , ranking fourth. Rights multiplier is balance sheet generalizations, show that assets, liabilities, and encourage the scale of rights, can reflect the most basic financial status, published the rights and interests of the media multiplier 1.53, ranking eighth, all these shows the operation state media published normal stable, with a further development potential. (Table 3)

\subsection{Financial Situation Analysis}

From the enterprise bear the financial risk ability's point of view, the asset-liability ratio, flow rate and ratio of the assessment hydraulic good index, including the current ratio can appraise enterprise assets total cash flow capacity, fast acting ratio is measured in a certain point can be converted into cash anytime assets by the ability of payment due debts. Generally speaking, the current ratio is in 2 or, the fast acting ratio is in 1 or more reasonable. Publication medium to asset ratio is $34.58 \%$, while the current domestic listed companies of the index $50 \%$ on average. Publication medium to asset ratio at a lower level, flow rate and fast acting ratio is also located in reasonable interval, on the one hand, that these companies have good financial support capacity, but on the other hand also shows that its financial leverage role did not get the full play. (Table 4)

In short, Liaoning Publish Media overall listing, in the business performance has certain improved, and its market effect or effective. Liaoning Publish Media in the capital operation performance is better than other media companies listed on the media plate. Of course, Liaoning Publish Media as the same version of the publishing industry enterprise, has its own particularity and the support of the country, but its performance has been much better than 2004 years in Hong Kong listing of the north green media stripped, and, more important, because is the overall listing, its public financial index and peel the listing of the enterprise, compared with no by the influence of the connection transaction, so the fair sex and credibility is strong.

\section{Result and Discussion}

The media has become China's media sector listed on the financing of the main development direction, at present made clear is preparing to go public, or the future of China's publishing and preparing to go public, Hunan publishing, Changjiang River publishing, three media group(Wang Sijing,2009), these media enterprise can be reference Liaoning Publish Media and adopt overall listed method. Liaoning Publish Media overall listing realizes from business assets to business assets editors listed separately listed the transformation of the bound, reflected the integrity of the industry, is China's media sector reform the system into a new stage of the sign, the overall listing is publishing media capital management of the inevitable development logic. Ensure that the media enterprise keep the enterprise in attributes and media properties, Liaoning Publish Media in the system in the certain arrangement, such as administrative level, to ensure that the right of state-owned capital, etc. Of course, the overall listing is not publication medium of innovation, in fact, about the "overall listing", in large state-owned enterprise listed process has a lot to try. Overall listing is the listed companies in China and the practical standard control behavior, this capital market deeper problem "permanent cure", is 
China's capital market standardization construction and the history of the development of choice(Li Fuxiang, Lu Ping,2007). In addition, the overall listing is to solve the controlling shareholder and interests of listed company not consistent, perfect governance structure of listed companies is an important system construction. But, at present, China's media industry and management was only think overall listing is a kind of more optimal mode of financing, but not yet realize can use the whole of the management of public media, and promote the sustainable development of the real media enterprise. Therefore, we should realize the whole from the strategic listed for media enterprise governance structure of influence.

\section{Conclusion}

Overall listing is to the enterprise management structure in which the influence of the influence of the connection transaction. Overall listing especially legal person after overall listing, the parent company of all assets into the listed company, both close 2 for one, make the state shares by the original hold a main body state parent into the country's state assets watchdog, the original exists in unlisted parent company and between the listed company to a large number of the fair associated trade, trade competition, and its parent company to encroach on the interests of the listed company situation will lose the existing infrastructure. Group affiliates and between parent and subsidiary companies of related transactions between, stood in the JiTuanCeng face consider it is no longer a group of related transactions, the group company and subsidiary company interests are united, the corporate governance structure of a company is improved. In addition, the company overall listing can solve the long-term existence of the listed company and the parent company because of complex correlation between trade and of generation gap, an illegal guarantee big shareholders a series of problems, such as help the listed company and the stock market regulating the operation, to protect the interests of small and medium shareholders. Even if it is just a realization related advocate course of study overall listing, because the listed company full business system formation, to the affiliated parties in the procurement, sales of greatly reduced dependence in a certain degree can also reduce related party transactions. For example, Liaoning Publish Media its original engaged in books, audio and video products wholesale and retail, printing enterprise required material supply, book publish and other member companies, and belong to the same group of the three press association between trade, and three press into the overall listing in the assets, reduce the associated enterprises occupy funds of listed company, and improve the performance of listed company operation and transparency. Liaoning Publish Media of overall listing, the business of the editors and get through the industry chain, make it become the first consolidation in the industry, which started the merger of high quality print resources integration of capital operation, in internal integration, the external expansion there are great as. Can say, listed in the first year of Liaoning Publish Media to watch. However, overall media itself is only for the listed to resolve their own system mechanism to provide a platform of the overall listing the outcome depends on media enterprise governance structure, overall listing still need to change after controlling shareholders of behavior, and establish an effective constraint mechanism, the effective incentive mechanism. After the overall listing, the media enterprise how to use capital market mechanism change the original low efficiency phenomenon, effectively solve the corporate governance problems, still needs further research.

\section{References}

Li Fuxiang, Lu Ping. (2007). Overall Listing and the ways to study the strategic significance of productive forces, Productivity Research, 2007, vol.5.

Li Yanrong. (2007). The listed company and its associated business of company value influence, Zhejiang provincial committee of the communist party of China party school journal, 2007, vol. 1.

Luo Zhenglin. (2006). The media capital market defect and transfer, Audio-visual industry, 2006, vol.5.

Wang Sijing. (2009). Phoenix company listed has set up a file in the review for publishing group listed, 21st Century Economic Report, 2009-3-6(7).

Xinhua Net. (2006-01-12). The state council of the communist party issued a deepening the reform of the cultural system some Suggestions, www.XINHUANET.com

Zhao Shuguang, Zhang Zhi'an. (2004). Media capital market case analysis, Huasha Press, 2004, p.111-112.

Zhao Tonggang, Wang Guangping. (2007). ZhongQing gas equity Harbin listing the sasac retain 1\% gold shares, China Securities Journal, 2007-7-30. 
Table 1. Liaoning Publish Media major accounting data and financial indicators from 2005 to 2009

(i) Profitability Index

\begin{tabular}{|llllll|}
\hline Financial Index & 2009 & 2008 & 2007 & 2006 & 2005 \\
\hline Diluted EPS & 0.2347 & 0.2097 & 0.1901 & 0.22 & 0.16 \\
\hline MRQ & 2.66 & 2.48 & 2.28 & 1.11 & -- \\
\hline CROA (\%) & 24.15 & 23.02 & 23.47 & 23.37 & 26.06 \\
\hline EBIT Margin (\%) & 7.38 & 6.17 & 7.32 & 7.86 & 9.5 \\
\hline ROA (\%) & 6.18 & 5.13 & 7.31 & 15.91 & -- \\
\hline ROE (\%) & 8.81 & 8.47 & 8.32 & 20.29 & -- \\
\hline
\end{tabular}

(ii) Management Efficiency Index

\begin{tabular}{|llllll|}
\hline Financial Index & 2009 & 2008 & 2007 & 2006 & 2005 \\
\hline Receivables Turnover & 4.05 & 4.65 & 4.74 & -- & -- \\
\hline Days Sales Outstanding & 88.95 & 77.35 & 75.93 & -- & -- \\
\hline Total Assets Turnover & 0.62 & 0.62 & 0.68 & -- & -- \\
\hline
\end{tabular}

(iii) Debt Paying Ability Index

\begin{tabular}{|llllll|}
\hline Financial Index & 2009 & 2008 & 2007 & 2006 & 2005 \\
\hline Current Ratio & 2.1 & 2.6 & 2.42 & 1.11 & -- \\
\hline Quick ratio & 1.42 & 1.88 & 1.78 & -- & -- \\
\hline Debt to asset ratio (\%) & 34.57 & 29.85 & 31.79 & 59.71 & -- \\
\hline
\end{tabular}

Table 2. 12 media listed company business and main association media subdivision

\begin{tabular}{|c|c|c|c|}
\hline Sub sector & Stock referred & divisionalisation & \multirow{2}{*}{$\begin{array}{l}\text { Main association media } \\
\text { Shanxi } \quad \text { Broadcasting } \\
\text { Group }\end{array}$} \\
\hline \multirow{5}{*}{$\begin{array}{l}\text { Television } \\
\text { network } \\
\text { device }\end{array}$} & $\begin{array}{l}\text { Broadcast } \\
\text { Television }\end{array}$ & 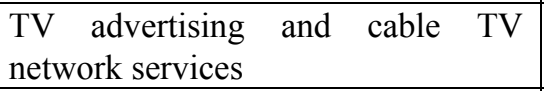 & \\
\hline & $\begin{array}{l}\text { Dianguang } \\
\text { Media }\end{array}$ & 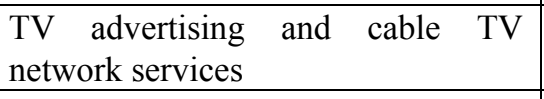 & $\begin{array}{l}\text { Hunan radio and } \\
\text { television group }\end{array}$ \\
\hline & Oriental Pearl & $\begin{array}{l}\text { TV advertising and cable network } \\
\text { services, tourism }\end{array}$ & $\begin{array}{l}\text { Shanghai culture of radio, } \\
\text { film and television group }\end{array}$ \\
\hline & CITIC Guoan & $\begin{array}{l}\text { Information technology services, } \\
\text { cable television network services }\end{array}$ & $\begin{array}{l}\text { CITIC of the national } \\
\text { security }\end{array}$ \\
\hline & YouXian & $\begin{array}{lll}\text { Radio and television } & \text { network } \\
\text { services }\end{array}$ & $\begin{array}{l}\text { Beijing radio, film and } \\
\text { television group }\end{array}$ \\
\hline Adver & B & $\begin{array}{l}\text { Outdoor advertising, the bus } \\
\text { operation }\end{array}$ & None \\
\hline $\begin{array}{l}\text { Film and } \\
\text { television } \\
\text { production }\end{array}$ & CTV & $\begin{array}{l}\text { Television programmed production } \\
\text { and tourism }\end{array}$ & CCTV \\
\hline $\begin{array}{l}\text { Industry } \\
\text { consulting } \\
\text { investment } \\
\text { and other }\end{array}$ & Huaw & $\begin{array}{l}\text { Multimedia content production and } \\
\text { management, etc. }\end{array}$ & $\begin{array}{l}\text { Shenzhen securities times } \\
\text { media Co., LTD, Shanxi } \\
\text { Chinese media group Co., } \\
\text { LTD, etc. }\end{array}$ \\
\hline \multirow{2}{*}{$\begin{array}{l}\text { Newspaper } \\
\mathrm{AD} \text { of } \\
\text { issuance }\end{array}$} & $\begin{array}{l}\text { CCID Media(ST } \\
\text { Media) }\end{array}$ & $\mathrm{AD}$, issue & $\begin{array}{l}\text { China's computer quote } \\
\text { CCID Media }\end{array}$ \\
\hline & Borui Spread & $\begin{array}{l}\text { Newspapers, } \\
\text { advertisement, issue }\end{array}$ & Chengdu Shangbao \\
\hline \multirow[t]{2}{*}{ Publishing } & Xinhua media & $\begin{array}{l}\text { Distribution, advertising agency, } \\
\text { logistics and distribution }\end{array}$ & $\begin{array}{l}\text { Shanghai Xinhua } \\
\text { Distribution Group }\end{array}$ \\
\hline & $\begin{array}{l}\text { Publication } \\
\text { Media }\end{array}$ & Published and distributed, printing & $\begin{array}{l}\text { Liaoning } \\
\text { Group }\end{array}$ \\
\hline
\end{tabular}

According to December 31, 2009 at the end of the 12 companies report, formulate dupont analysis form and the asset-liability ratio index table: 
Table 3. 12 listed media companies' dupont analysis in 2009

\begin{tabular}{|c|c|c|c|c|c|c|}
\hline Subsector & Stock referred & ROE & ROA & EBIT Margin & CROA & Equity multiplier \\
\hline \multirow{6}{*}{$\begin{array}{l}\text { Television } \\
\text { Network Device }\end{array}$} & Broadcast Television & $6.45 \%$ & $2.89 \%$ & $8.22 \%$ & 0.35 & 2.31 \\
\hline & Dianguang Media & $1.51 \%$ & $0.34 \%$ & $0.70 \%$ & 0.49 & 3.31 \\
\hline & Oriental Pearl & $5.77 \%$ & $4.17 \%$ & $23.62 \%$ & 0.18 & 1.24 \\
\hline & CITIC Guoan & $10.62 \%$ & $5.77 \%$ & $31.08 \%$ & 0.19 & 1.83 \\
\hline & Gehua YouXian & $5.62 \%$ & $4.38 \%$ & $23.63 \%$ & 0.19 & 1.31 \\
\hline & Average & $6.00 \%$ & $3.51 \%$ & $17.45 \%$ & 0.28 & 2.00 \\
\hline Advertising & Beiba Media & $11.85 \%$ & $6.45 \%$ & $8.18 \%$ & 0.79 & 1.55 \\
\hline $\begin{array}{ll}\text { Film } & \text { and } \\
\text { Television } & \\
\text { Production } & \end{array}$ & CTV media & $12.25 \%$ & $7.08 \%$ & $8.46 \%$ & 0.84 & 1.49 \\
\hline $\begin{array}{l}\text { Industry } \\
\text { Consulting } \\
\text { Investment and } \\
\text { Other } \\
\end{array}$ & Huawen media & $7.20 \%$ & $4.23 \%$ & $6.49 \%$ & 0.65 & 1.38 \\
\hline \multirow[t]{3}{*}{$\begin{array}{l}\text { Newspaper AD } \\
\text { and Issuance }\end{array}$} & $\begin{array}{ll}\text { CCID } & \text { Media(ST } \\
\text { Media) } & \\
\end{array}$ & $-94.43 \%$ & $-28.39 \%$ & $-75.52 \%$ & 0.38 & 2.86 \\
\hline & Borui Spread & $20.21 \%$ & $15.14 \%$ & $28.50 \%$ & 0.53 & 1.52 \\
\hline & Average & $-37.11 \%$ & $-6.62 \%$ & $-23.51 \%$ & 0.45 & 2.19 \\
\hline \multirow[t]{2}{*}{ Publishing } & Xinhua media & $11.14 \%$ & $6.61 \%$ & $10.23 \%$ & 0.65 & 1.50 \\
\hline & Publication Media & $8.81 \%$ & $6.18 \%$ & $10.01 \%$ & 0.62 & 1.53 \\
\hline
\end{tabular}

Table 4. 12 listed media companies' asset ratio index in 2009

\begin{tabular}{|c|c|c|c|c|}
\hline Subsector & Stock referred & $\begin{array}{l}\text { Debt to asset } \\
\text { ratio }\end{array}$ & $\begin{array}{l}\text { Current } \\
\text { Ratio }\end{array}$ & Quick ratio \\
\hline \multirow{6}{*}{$\begin{array}{l}\text { Television } \\
\text { Network Device }\end{array}$} & Broadcast Television & $56.63 \%$ & 0.26 & 0.19 \\
\hline & Dianguang Media & $69.80 \%$ & 1.21 & 0.87 \\
\hline & Oriental Pearl & $19.53 \%$ & 1.89 & 1.13 \\
\hline & CITIC Guoan & $45.24 \%$ & 1.67 & 1.24 \\
\hline & Gehua YouXian & $23.70 \%$ & 1.87 & 1.62 \\
\hline & Average & $42.98 \%$ & 1.38 & 1.01 \\
\hline Advertising & Beiba Media & $35.67 \%$ & 2.35 & 2.11 \\
\hline $\begin{array}{ll}\text { Film } & \text { and } \\
\text { Television } & \\
\text { Production } & \end{array}$ & CTV media & $32.69 \%$ & 2.10 & 1.73 \\
\hline $\begin{array}{l}\text { Industry } \\
\text { Consulting } \\
\text { Investment and } \\
\text { Other }\end{array}$ & Huawen media & $27.34 \%$ & 1.97 & 1.68 \\
\hline \multirow{3}{*}{$\begin{array}{l}\text { Newspaper AD } \\
\text { and Issuance }\end{array}$} & CCID Media(ST Media) & $65.00 \%$ & 0.63 & 0.55 \\
\hline & Borui Spread & $34.13 \%$ & 1.34 & 1.27 \\
\hline & Average & $35.78 \%$ & 1.67 & 1.56 \\
\hline \multirow[t]{2}{*}{ Publishing } & Xinhua media & $33.55 \%$ & 1.46 & 1.00 \\
\hline & Publication Media & $34.58 \%$ & 2.10 & 1.42 \\
\hline
\end{tabular}

